\title{
TEKNIK PEMERIKSAAN USG GINJAL PADA KLINIS HYDRONEPHROSIS : STUDI KASUS
}

\author{
Gando Sari ${ }^{1}$, Nursama Heru ${ }^{2}$, Darusalam ${ }^{3}$ \\ 1,2,3) Jurusan Teknik Radiodiagnostik dan Radioterapi, Politeknik Kesehatan Kemenkes Jakarta II, \\ Jakarta, Indonesia \\ E - mail : bundagandosari@gmail.com
}

\begin{abstract}
Hydronephrosis is a renal swelling due to urine buildup. Symptom of hydronephrosis is according to acute or chronis blockage, partly or all of renal, happened unilateral or bilateral. Blockage happened on urethra causes of illness from uretha distention. Urine can not flow by normally as usually as make new infection which could be stone renal and bleeding on urine. If blockage happened, it causes of failure renal. To evalution hydronephrosis can do by ultrasonografi examination.
\end{abstract}

Keywords : Hydronephrosis, ultrasonografi (USG), renal, uretha.

\begin{abstract}
Hydronefrosis merupakan pembengkakan ginjal akibat penumpukan urine. Tanda - tanda dan gejala hidronefrosis tergantung pada apakah penyumbatan tersebut terjadi secara akut atau kronis, sebagian atau seluruhnya, unilateral atau bilateral. Penyumbatan terjadi pada uretra atau kandung kemih dapat menyebabkan rasa sakit yang dihasilkan dari distensi kandung kemih. Terhalangnya aliran urin sering mengakibatkan infeksi saluran kemih yang dapat mengarah pada pengembangan batu ginjal dan darah atau nanah dalam urine. Jika penyumbatan lengkap terjadi, hal tersebut dapat menyebabkan gagal ginjal. Untuk mengetahui adanya hydronephrosis tersebut maka dapat dilakukan pemeriksaan Ultrasonografi (USG) ginjal.
\end{abstract}

Kata kunci : Hydronephrosis, Ultrasonografi (USG), ginjal, kandung kemih.

\section{PENDAHULUAN}

Ginjal memiliki fungsi untuk mengatur sekresi urine dan mengeluarkan zat - zat beracun di dalam tubuh. Hydronephrosis merupakan pembengkakan ginjal akibat penumpukan urine (1-3). Pembengkakan ini terjadi akibat adanya gangguan pada saluran kemih yang letaknya ada di bawah dari ginjal dan penyebabnya dapat bermacam - macam. Apabila tejadi gangguan dari saluran kandung kemih maka aliran urine akan terhambat sehingga akan menggenangi ginjal dan menyebabkan pelebaran dari saluransaluran yang ada di dalam ginjal (4-6). Normalnya, darah yang masuk ke dalam ginjal kiri dan kanan akan di saring dan zat - zat yang tidak diperlukan oleh tubuh akan dibuang melalui air kencing/urine (7). Setelah itu, urin akan masuk ke kandung kemih melalui ureter kiri dan kanan. Di dalam kandung kemih, urine akan ditampung sementara hingga penuh lalu akan dikeluarkan melalui urethra ke luar dari tubuh. Terhalangnya aliran urine sering mengakibatkan infeksi saluran kemih yang dapat mengarah pada pengembangan batu ginjal dan darah atau nanah dalam urine. Penyakit ini dapat bersifat bawaan lahir maupun didapat saat dewasa $(8,9)$.

Gejala hydronephrosis dapat ditandai dengan nyeri pada perut karena terjadi distensi karena terjadi pelebaran dari kandung kemih, 
tidak dapat kencing, infeksi saluran perkencingan dan terjadi gangguan frekuensi buang air kecil. Ciri - ciri penderita hydronephrosis memiliki tekanan darah tinggi, demam, nyeri pada pinggang, kandung kemih dan ginjal terasa membesar serta kaki dan mata akan membengkak (10-12).

Untuk memastikan seseorang menderita hydronephrosis dapat dilakukan pemeriksaan diantaranya peningkatan kadar ureum dan kreatinin dalam darah terutama terjadi apabila sumbatan terbentuk di kedua ureter, kiri dan kanan. Gangguan kadar elektrolit dalam darah, dapat terjadi peningkatan dari kadar natriumdan kalium. Pemeriksaan urin lengkap dapat menunjukkan peningkatan leukosit atau sel darah putih, eritrosit atau sel darah merah, maupun bakteri karena disebabkan oleh infeksi atau adanya batu pada saluran perkencingan. Pemeriksaan intravenous pylogram (IVP), pemeriksaan ini menggunakan kontras atau zat untuk mengisi saluran kemih. Karena pemeriksaan ini menggunakan kontras dan kontras dapat memperparah fungsi ginjal yang sudah menurun maka pemeriksaan ini tidak disarankan pada penderita yang telah mengalami penurunan fungsi ginjal. CT Scan abdomen berfungsi untuk mengetahui adanya obstruksi, MRI dilakukan apabila beberapa pemeriksaan tersebut tidak dapat mendiagnosa kelainan, dan pemeriksaan Ultrasonografi (USG) merupakan pemeriksaan yang tepat untuk dilakukan pada penderita hydronephrosis karena pemeriksaan ini tidak bersifat non invasive sehingga aman dilakukan, pada pemeriksaan USG ini memiliki tujuan untuk melihat ukuran dari ginjal dan kandung kemih, serta bentuk dari saluran kandung kemih (13-20).

\section{Studi Kasus}

Pasien Tn. S, 49 tahun datang ke bagian radiologi dengan keluhan nyeri pinggang yang hebat. Dokter yang menangani pasien mencurigai adanya kelainan pada ginjal. Berdasarkan anamnesa tersebut dokter memberikan surat permintaan USG ginjal.

Pemeriksaan USG ginjal tidak memerlukan persiapan khusus, hanya saja pasien perlu banyak minum kurang lebih sebanyak 1 liter air minum, 1 jam sebelum pemeriksaan berlangsung dan tahan buang air kecil, bila pasien menggunakan cateter, cateter harus diikat / diklem sebelum dan selama pemeriksaan berlangsung. Hal ini bertujuan untuk melihat buli-buli maupun prostat, karena pemeriksaan USG ginjal biasanya dilakukan juga pemeriksaan USG buli-buli dan USG Prostat pada pasien laki-laki.

Pasien supine diatas meja pemeriksaan dan kepala pasien diberi bantal dan selimut agar merasa nyaman. Pasien diminta untuk melonggarkan dan menurunkan pakaian bagian bawah untuk memudahkan saat pemeriksaan berlangsung. Lindungi pakaian pasien dengan tissue. Lakukan pengisian identitas (ID) pasien. Gunakan jelly sesuai kebutuhan. Pemeriksaan menggunakan alat USG merk Philips dan transduser yang digunakan adalah transduser konveks dengan frekuensi 3.5 MHz. Pada opsi pemilihan fungsi pilih penggunaan abdomen, atur TGC, gain Depth serta fokus untuk mendapatkan gambaran yang optimal.

Skening dilakukan dengan posisi transduser longitudinal. Skening pada ginjal kanan dalam posisi pasien supine dengan meletakkan transduser pada sisi kanan abdomen yaitu pada midaxillar line kanan maupun tegak lurus pada midclavicular line di bagian intercostal atau subcostal, ginjal kanan akan terlihat pada posisi supine, dengan menggunakan liver sebagai acoustic window.

Bila hasil gambaran dalam posisi pasien supine kurang optimal, instruksikan pasien berbaring pada sisi kiri (Left Lateral Decubitus) dengan tangan kanan diletakan keatas kepala agar costae menjadi regang dan memudahkan dalam melakukan observasi ginjal kanan pasien. Lakukan pemeriksaan ginjal kiri dengan prosedur yang sama seperti skening ginjal kanan, dengan menggunakan spleen sebagai acoustic window. Bila gambaran pada posisi supine kurang optimal, instruksikan posisi pasien berbaring pada sisi kanan (Right Lateral Decubitus) dengan tangan kiri diletakan diatas kepala pasien agar costae menjadi regang dan mudah dalam melakukan observasi ginjal kiri pasien. Gambar diambil saat pasien menahan napas pada inspirasi penuh atau bila pasien sulit menahan napas instruksikan pasien mengembungkan bagian perutnya, setelah itu lakukan sweeping dari arah medial kelateral untuk mendapatkan gambaran ginjal yang optimal, transduser diletakkan sesuai dengan mengikuti organ. Lakukan pengukuran panjang dan lebar organ ginjal serta ureter yang terdapat pada ginjal untuk dievaluasi. 
Gambar teknik skening sebagai berikut :

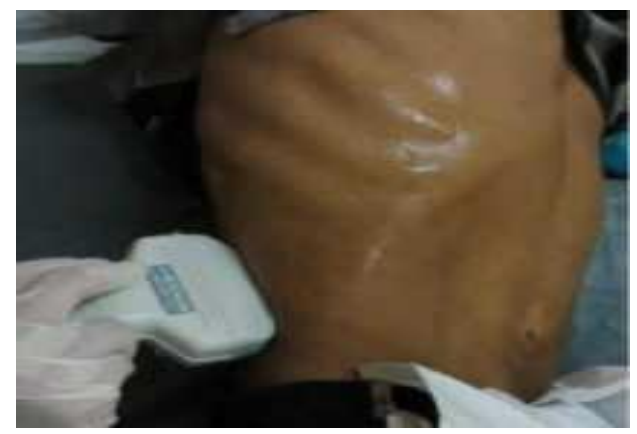

Gambar 1.

Skening longitudinal Ginjal Kanan Pada Pasien Tn. S, Posisi Pasien LLD.

\section{Hasil Dan Pembahasan}

Pemeriksaan USG ginjal pada pasien lakilaki Tn. S berumur 49 tahun, dengan klinis hydronephrosis atau pembengkakan ginjal menggunakan 2 teknik skening USG, yaitu teknik skening longitudinal dan transversal. dan menggunakan transduser konveks dengan frekuensi $3.5 \mathrm{MHz}$.

Pasien diinstruksikan terlebih dahulu untuk minum air putih 1 liter dan menahan agar tidak buang air kecil. Kemudian melakukan pemeriksaan USG ginjal.

Gambaran teknik skening sebagai berikut :

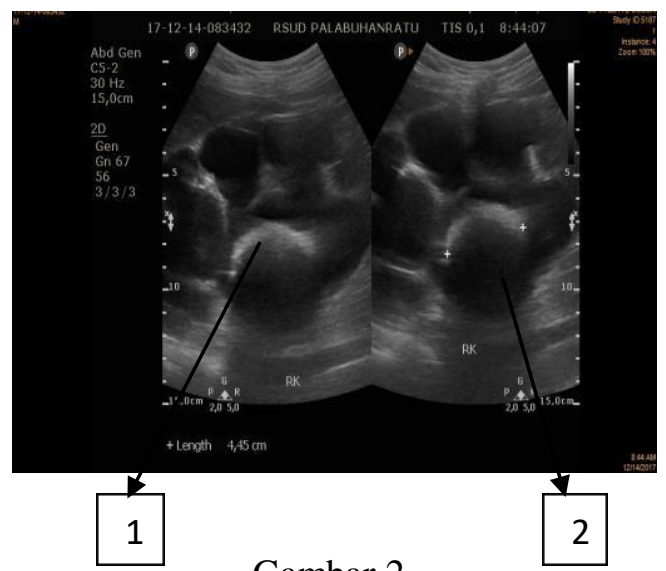

Gambar 2.

Hasil gambar skening ginjal kanan.

Keterangan gambar : tampak gambaran multiple hyperechoic yang merupakan gambaran batu (1), dan unechoic yang merupakan gambaran hydronephrosis (2).

Berdasarkan hasil gambaran ultasonografi ginjal yang dilakukan didapatkan hasil : Sugestif batu multiple di ginjal kanan dengan ukuran terbesar $+/-4,45 \mathrm{~cm}$, hydronephrosis ginjal kanan grade IV, hidroureter kanan. Kemudian dokter yang melakukan ekspertise menyarankan untuk mengkonfirmasi dengan laboratorium dan klinis serta CT scan abdomen tanpa kontras.

\section{Kesimpulan}

Studi kasus ini dilakukan dengan observasi langsung. Ginjal memiliki fungsi untuk mengatur sekresi dan mengeluarkan zat - zat beracun di dalam tubuh. Hydronephrosis salah satu kelainan yang terjadi pada ginjal, pembengkakan ginjal terjadi akibat penumpukan urine. Pada klinis hydronephrosis dapat dilakukan beberapa pemeriksaan radiologi, namun pemeriksaan USG salah satu pemeriksaan yang aman, tepat dan akurat untuk mengidentifikasi hydronephrosis.

\section{Daftar Pustaka}

1. Šmon F. History of the term " pelvis renalis "History of the term " pelvis renalis ." 2014;(June).

2. Gleason PE, Kelalis PP, Husmann DA, Kramer SA. Hydronephrosis in Renal Ectopia: Incidence, Etiology and Significance. J Urol [Internet]. 1994;151(6):1660-1. Available from: http://linkinghub.elsevier.com/retrieve/pii/ S0022534717353387

3. Sandberg JM, Dyer RB, Mirzazadeh M. A Rare Case Report of Hydronephrosis and Acute Kidney Injury Secondary to Gonadal Vein Thrombosis in a Young Male. J Endourol Case Reports [Internet]. 2017;3(1):119-22. Available from: http://online.liebertpub.com/doi/10.1089/cr en.2017.0063

4. Anatomy and Physiology Related To Clinical Pathology.

5. Tucker louise. anatomy \& physiology. resivered. 2008.

6. Wilson ross and. anatomy and physiology in health and ilness. ninth edit. 2005.

7. Vilalta L, Dominguez E, Altuzarra R, Sibera N, Espada Y, Novellas R, et al. Imaging Diagnosis-Radiography and Ultrasonography of Bilateral Congenital Ureterovesical Junction Stenosis Causing Hydronephrosis and Hydroureter in a Ferret 
(

Mustela Putorius Furo). Vet Radiol Ultrasound. 2017;58(3):E31-6.

8. Farr A, Ott J, Kueronya V, Margreiter M, Javadli E, Einig S, et al. The association between maternal hydronephrosis and acute flank pain during pregnancy: a prospective pilotstudy. J Matern Neonatal

9. Thorup J, Mortensen T, Diemer H, Johnsen A, Nielsen OH. The prognosis of surgically treated congenital hydronephrosis after diagnosis in utero. J Urol [Internet]. 1985;134(5):914-7. Available from:

http://dx.doi.org/10.1016/S00225347(17)47521-5

10. Glick PL, Harrison MR, Golbus MS, Adzick NS, Filly RA, Callen PW, et al. Management of the fetus with congenital hydronephrosis II: Prognostic criteria and selection for treatment. J Pediatr Surg. 1985;20(4):376-87.

11. Fung LEOCT, Khoury AE, Mclorie GA, Chait PG, Churchill BM. Individualized Pressure Flow Criteria "I. 1995;

12. Hochberg EP, Bierer MF, Winkfield $\mathrm{KM}$, Chen Y-B, Muse V V., Louissaint A. Case 11-2017 - A 61Year-Old Woman with Leg Swelling, Back Pain, and Hydronephrosis. N Engl J Med [Internet]. 2017;376(15):1461-71. Available from:

http://www.nejm.org/doi/10.1056/NEJ Mcp c1616023

13. Dudley JA, Haworth JM, McGraw ME, Frank JD, Tizard EJ. Clinical relevance and implications of antenatal hydronephrosis. Arch Dis Child FetalNeonatal Ed [Internet]. 1997;76(1):F31-4.
Available from:

http://www.pubmedcentral.nih.gov/art icler

ender.fcgi ?artid=1720612\&tool=pmc entre $z \&$ rendertype $=a b s t r a c t$

14. Evaluation of ultrasonographic diagnostic criteria for autosomal dominant polycystic kidney disease 1 .

15. Sand (20):2417-21. Available from: http://dx.doi. Sanders RC, Bearman S. B-Scan Ultrasound in the Diagnosis of Hydronephrosis. 1973;(March):37582.

16. Dalla-Palma L, Bazzocchi M, PozziMucelli RS, Stacul F, Rossi M, Agostini R. Ultrasonography in the diagnosis of hydronephrosis in patients with normal renal function. Urol Radiol. 1983;5(1):221-6.

17. Zhu Y, Wu Y, Zhang Z. [MR urography in the diagnosis of upper urinary tract obstruction]. Zhonghua Wai Ke Za Zhi. 1999;37(8):490-1.

18. Stuck KJ, Koff A, Silver TM. Ultrasonic Dysplastic Diagnostic Features Kidney: Criteria " of Multicystic Expanded. :217-21.

19. Yuruk E, Tuken M, Sulejman S, Colakerol A, Serefoglu EC, Sarica K, et al. Computerized tomography attenuation values can be used to differentiate hydronephrosis from pyonephrosis. World J Urol. 2017;35(3):437-42.

20. Leo M, Langlois B, Pare J, Mitchell $\mathrm{P}$, Linden $\mathrm{J}$, Nelson $\mathrm{K}$, et al. Ultrasound vs. Computed Tomography for Severity of Hydronephrosis and Its Importance in Renal Colic. West J Emerg Med [Internet]. 2017;18(4):559-68. Available from: http://escholarship.org/uc/item/3h20q 41v 